\title{
Multigene phylogenetic and population differentiation data confirm the existence of a cryptic species within Chrysoporthe cubensis
}

\author{
Nicolaas A. van der Merwe ${ }^{1,3}$, Marieka Gryzenhout ${ }^{3}$, Emma T. Steenkamp ${ }^{2,3}$, Brenda D. \\ Wingfield $^{1,3}$ and Michael J. Wingfield ${ }^{1,3}$
}

(1) Department of Genetics, University of Pretoria, Pretoria, South Africa

(2) Department of Microbiology and Plant Pathology, University of Pretoria, Pretoria, South Africa

(3) Forestry and Agricultural Biotechnology Institute, University of Pretoria, Pretoria, South Africa

Nicolaas A. van der Merwe

Email: albe.vdmerwe@up.ac.za

\begin{abstract}
Chrysoporthe cubensis is one of the most important pathogens of Eucalyptus. Based on phylogenetic evidence and geographic origin, isolates of this fungus are known to reside in distinct 'South America' and 'Southeast Asia' clades. In this study, reproductive isolation amongst these isolates of $C$. cubensis was tested using gene flow statistics for 12 polymorphic loci, and to support these data, phylogenetic affiliations based on gene trees and a multigene phylogeny were used. Gene flow statistics between populations, and relative to the closely related Chrysoporthe austroafricana, were low and not significantly different $(\mathrm{P}<0.05)$. Additionally, phylogenetic analyses of DNA sequence data for four gene regions convincingly distinguished the two subclades of $C$. cubensis. Isolates in the Southeast Asian subclade are described in the new species, Chrysoporthe deuterocubensis. Chrysoporthe cubensis and C. deuterocubensis represent closely related fungi that are thought to be native to South America and Southeast Asia, respectively. A technique is presented that allows for rapid differentiation between these species and that will aid in quarantine procedures to limit their spread to new environments.
\end{abstract}

\section{Introduction}

Chrysoporthe cubensis causes a serious stem canker disease of Eucalyptus (Myrtaceae, Myrtales), commonly known as Chrysoporthe canker (Hodges 1980; Gryzenhout et al. 2009). Until 2004, C. cubensis and the closely related Chrysoporthe austroafricana were treated as Cryphonectria cubensis (Gryzenhout et al. 2004). Their recognition as distinct species in the new genus Chrysoporthe, was facilitated by DNA sequence-based phylogenetic analyses. Despite the fact that both of these species are associated with Myrtalean hosts, their geographic distributions do not overlap. Chrysoporthe cubensis is considered native to South and Central America and Southeast Asia, due to its association with native woody Melastomataceae (Myburg et al. 1999a; Roux et al. 2005; Nakabonge et al. 2006) such as Miconia and Melastoma species (Gryzenhout et al. 2009). In contrast, disease surveys on the African continent revealed that Syzygium species in the Myrtales (Heath et al. 2006; Nakabonge et al. 2006) are commonly infected by C. austroafricana, which suggest an African origin for this fungus (Gryzenhout et al. 2009).

Previous phylogenetic studies based on the rRNA internal transcribed spacer (ITS) regions, $\beta$ tubulin and histone $\mathrm{H} 3$ genes have consistently separated $C$. cubensis into two well-supported 
clades (Myburg et al. 1999b; Myburg et al. 2002; Myburg et al. 2003; Gryzenhout et al. 2004; Myburg et al. 2004; Gryzenhout et al. 2006a; Gryzenhout et al. 2006c). One of these, referred to as the South American clade, accommodates isolates from countries in South and Central America, as well as likely introductions into western African countries such as Cameroon, Congo and the Democratic Republic of the Congo (Myburg et al. 2002; Myburg et al. 2003; Roux et al. 2003; Gryzenhout et al. 2006b). The second clade accommodates isolates from Southeast Asian countries such as Indonesia and Thailand, as well as likely introductions into Australia, China, Hawaii (Myburg et al. 2002; Myburg et al. 2003; Gryzenhout et al. 2006b), and several countries in Eastern Africa (Myburg et al. 2003; Gryzenhout et al. 2006b; Nakabonge et al. 2006). Although isolates in these clades have distinct and nonoverlapping geographic distributions (Gryzenhout et al. 2004), they all include native hosts in the Melastomataceae. Where they have been found on trees in the Myrtaceae such as eucalypts and clove (Syzygium aromaticum), these are considered to be host shifts (Slippers et al. 2005) either arising from planting these trees in areas where the fungus occurs on related native Myrtales, or through accidental introductions associated with agriculture and forestry (Wingfield 2003; Gryzenhout et al. 2009). There are also no obvious morphological characters that have been shown to distinguish specimens or isolates representing the two phylogenetic clades of C. cubensis (Gryzenhout et al. 2004).

So-called cryptic species, or species that are distinct but indistinguishable based on morphology, began to emerge when phylogenetic inference arose as an effective means to characterise fungal taxa (Taylor et al. 1999). Well-known examples of taxa harbouring cryptic species include Coccidioides immitis (Burt et al. 1996; Koufopanou et al. 2001), Aspergillus flavus (Geiser et al. 1998), Aspergillus fumigatus (Pringle et al. 2005), Fusarium subglutinans (Steenkamp et al. 2002), Amanita muscaria (Geml et al. 2006), Neofusicoccum parvum and Neofusicoccum ribis ([Pavlic et al. 2008; 2009). These species are mainly separated based on DNA sequence comparisons, and in some cases diagnostic morphological characters have later been found to support their separation (Geiser et al. 2000; Taylor et al. 2000; O’Donnell et al. 2004; Pavlic et al. 2008).

In addition to making use of phylogenetic species recognition (Hudson and Coyne 2002; De Queiros 2007), specifically the genealogical concordance version of this approach (Taylor et al. 2000), cryptic species can be separated based on low levels of interspecific gene flow (Taylor et al. 2000; Sites and Marshall 2003). This is because continuous admixture between disparately distributed populations can be detected from discordant genealogies for multiple genetic loci and/or low levels of population differentiation and high numbers of migrants (Geiser et al. 1998; Fisher et al. 2002; Zhou et al. 2007; Milgroom et al. 2008). Conversely, concordance among genealogies for multiple loci and diminished gene flow due to ecological, geographical or historical processes are generally regarded as useful indicators of species divergence (Avise and Wollenberg 1997; Barraclough and Nee 2001).

Chrysoporthe cubensis is an economically important fungal pathogen of substantial quarantine importance. Chrysoporthe canker has had a significant impact on one of the most important sources of paper pulp in the world, and has distinctly shaped Eucalyptus forestry globally (Wingfield 2003). Regulations to control its movement are frustrated by a vague taxonomic definition and the fact that very obvious phylogenetic differences amongst isolates are overlooked due to isolates residing under a single name. The aim of this study was, therefore, to gain a refined understanding of isolates residing in the two phylogenetic clades of $C$. cubensis. This was achieved using a population genetic approach based on polymorphic marker data to recognize distinct species as well as multigene phylogenetic inference to study relationships among isolates and species. 


\section{Materials and Methods}

\section{Isolates and DNA extraction}

Eight isolates of Chrysoporthe cubensis representing the two phylogenetic clades, as well as representatives for the other known species of Chrysoporthe (Table 1), were used to construct gene genealogies and a multigene phylogeny. Isolates used for population genetic comparisons included 112 C. cubensis isolates obtained from Eucalyptus trees and specifically chosen to represent a wide geographic distribution encompassing the largest possible level of diversity. Of these, a total of 79 isolates potentially represented the South American clade and were obtained from Cuba (10), Colombia (34), Mexico (32), and the Democratic Republic of Congo (3). Populations from Southeast Asia (33 isolates) were represented by 16 isolates from Indonesia and 17 from Vietnam. For comparative purposes, the isolates used for the population genetics analyses included a population of 97 Chrysoporthe austroafricana isolates from South and Eastern Africa and included those from Eucalyptus sp. in Zambia (5), Mozambique (10) and South Africa (29), Syzygium sp. in Mozambique (12) and South Africa (26), and Tibouchina sp. in South Africa (15). All isolates are maintained in the culture collection (CMW) of the Forestry and Agricultural Biotechnology Institute (FABI), University of Pretoria, Pretoria, South Africa.

Table 1. Isolates of Chrysoporthe sp. used in the multigene phylogenetic studies, and the GenBank accession numbers for the sequences included in phylogenetic analyses.

\begin{tabular}{|c|c|c|c|c|c|c|c|}
\hline Taxon & Origin & $\begin{array}{l}\text { Isolate } \\
\text { number }\end{array}$ & ACT & BT1 & BT2 & $\mathrm{EF}-1 \alpha$ & ITS \\
\hline \multirow[t]{2}{*}{ Chrysoparthe austroafricana } & South Africa & CMW9327 & GQ290173 & GQ290185 & CQ290194 & GQ290151 & CQ290158 \\
\hline & & CMW10192 & GQ290163 & GQ290176 & CQ290187 & GQ290138 & AY 214299 \\
\hline \multirow[t]{4}{*}{ Chrysoporthe cubensis } & Colombia & CMW10028 & GQ290161 & GQ290175 & CQ290186 & CQ290137 & CQ290153 \\
\hline & $\begin{array}{l}\text { Republic } \\
\text { of Congo }\end{array}$ & CMW10669 & GQ290171 & GQ290177 & CQ290188 & GQ290140 & GQ290154 \\
\hline & Brazil & CMW10778 & GQ290165 & GQ290178 & CQ290189 & $\mathrm{GQ290141}$ & CQ290155 \\
\hline & Mexico & CMW12734 & GQ290159 & DQ368791 & GQ290191 & CQ290146 & DQ368769 \\
\hline Chrysoparthe & Austraba & CMW2631 & GQ290174 & GQ290184 & AF543825 & GQ290149 & GQ290157 \\
\hline \multirow[t]{3}{*}{ deuterocubensis } & Indonesia & CMW8650 & GQ290172 & AY084024 & GQ290193 & GQ290150 & AY 084001 \\
\hline & Singapore & CMW12745 & GQ290160 & GQ290183 & DQ368781 & CQ290147 & DQ368764 \\
\hline & Thailand & CMW17178 & GQ290164 & DQ368785 & $\mathrm{CQ} 290192$ & CQ290148 & DQ368766 \\
\hline Chrysoparthe daradensis & Ecuador & CMW11287 & GQ290167 & GQ290179 & CQ290190 & CQ290142 & CQ290156 \\
\hline \multirow[t]{2}{*}{ Chrysoparthella hodgesiana } & Colombia & CMW9995 & GQ290162 & AY956978 & AY956977 & CQ290152 & AY956969 \\
\hline & & CMW10625 & GQ290170 & AY262391 & AY956979 & GQ290139 & AY262399 \\
\hline \multirow[t]{2}{*}{ Chrysoparthe incpina } & & CMW12727 & GQ290169 & GQ290180 & DQ368806 & CQ290143 & DQ368777 \\
\hline & & CMW12731 & GQ290168 & GQ290182 & DQ368811 & GQ290145 & DQ368779 \\
\hline Amphilogia gyrosab & Taiwan & BCRC34145 & EF025600 & EF025615 & EFCO5615 & - & EFO26147 \\
\hline
\end{tabular}

a CMW - culture collection of the FABI, University of Pretoria, Pretoria, South Africa; BCRC - Bioresource Collection and Research Center, Taiwan.

b Amphilogia gyrosa was used as an outgroup taxon (fu et al. 2007).

Isolates were grown on $20 \% \mathrm{w} / \mathrm{v}$ malt extract agar or inoculated into $800 \mu \mathrm{l}$ malt extract broth in $1.5 \mathrm{ml}$ microcentrifuge tubes. After 1 week of growth in the dark at $25^{\circ} \mathrm{C}$, fungal mycelium was harvested. Total genomic DNA was extracted using a previously published method based on hexadecyltrimethylammonium bromide (CTAB) and standard phenol-chloroform extractions (Steenkamp et al. 1999).

\section{Phylogenetic analyses}

Polymerase chain reactions (PCR) were used to amplify rRNA ITS and the intron or noncoding regions of the Actin (ACT), $\beta$-tubulin (Bt1 and $\mathrm{Bt} 2$ primer sets), and eukaryotic translation elongation factor 1- $\alpha(\mathrm{EF}-1 \alpha)$ genes (White et al. 1990; Glass and Donaldson 1995; Carbone and Kohn 1999) for phylogenetic comparisons using a subset of isolates. Each PCR reaction contained 0.1 U SuperTherm Taq DNA polymerase enzyme (Southern Cross Biotechnology, South Africa), 25 
$\mathrm{mM} \mathrm{MgCl} 2,2 \mu \mathrm{M}$ of each primer, $200 \mu \mathrm{M}$ of each dNTP, $25 \mathrm{ng}$ genomic DNA and $1.5 \mu 110 \times$ PCR buffer. Reaction volumes were adjusted to $15 \mu \mathrm{l}$ using sterile deionised water. Reactions were performed using a GeneAmp® PCR System 9700 thermocycler (Applied Biosystems, USA) with the cycling protocol described by Glass \& Donaldson (1995). Reaction annealing temperatures were $55{ }^{\circ} \mathrm{C}$ for the ITS and EF- $1 \alpha$ loci, and $62{ }^{\circ} \mathrm{C}$ for the ACT locus and two regions of the $\beta$-tubulin gene (BT1 and BT2). Amplicon sizes were visually confirmed using agarose gel $(2 \% \mathrm{w} / \mathrm{v})$ electrophoresis, after which the PCR products were purified using polyethylene glycol precipitation (Steenkamp et al. 2006). PCR products were sequenced using BigDye ${ }^{\circledR}$ dye terminator chemistry (Applied Biosystems, USA) and an ABI ${ }^{\mathrm{TM}}$ Prism ${ }^{\circledR} 3500$ automated sequencing machine (Applied Biosystems).

DNA sequences for each locus were aligned using Muscle 3.6 (Edgar 2004) and manually adjusted using SeaView 2.2 (Galtier et al. 1996). The alignments were amended with ACT, $\beta$-tubulin and ITS sequences from the NCBI (National Center for Biotechnology Information,

http://www.ncbi.nlm.nih.gov) nucleotide database for a closely related taxon, Amphilogia gyrosa, to serve as outgroup (Ju et al. 2007). The incongruence length difference (ILD) test (Farris et al. 1995; Cunningham 1997) implemented in PAUP* 4.0b10 (Swofford 2002), was used to test whether the resulting alignments represent homogenous partitions. In order to test for phylogenetic signal, the $\mathrm{g}_{1}$ statistic (Hillis \& Huelsenbeck 1992) for each data set was calculated using parsimony methods in PAUP* 4.0b10. Individual and combined gene alignments were subjected to maximum likelihood (ML) analyses using PhyML 2.4.5 (Guindon \& Gascuel 2003), incorporating the GTR + G + I model of evolution as determined by jModelTest 0.1.1 (Posada 2008). The confidence in branches was tested using 1000 bootstrap replicates for each analysis. Phylogenic trees were displayed and annotated using MEGA4 (Tamura et al. 2007).

\section{Population genetic analyses}

In order to determine whether populations of isolates representing Chrysoporthe austroafricana and the two clades of Chrysoporthe cubensis were significantly different from each other, population differentiation and gene flow between these species were estimated. For this purpose 12 microsatellite markers (Table 2) were used following previously published methods (van der Merwe et al. 2003).

Table 2. Primers for polymorphic DNA markers used in this study.

\begin{tabular}{|c|c|c|c|c|}
\hline Locus name ${ }^{a}$ & Dye label & Bin size (bp) & Primer name & Primer sequence $\left(5^{\prime}-3^{\prime}\right)$ \\
\hline \multirow[t]{2}{*}{ CCPMC } & vIC & $190-212$ & PMCF & ttgegtatggaaatgacg \\
\hline & & & PMCR & atggcgettgtatagagca \\
\hline \multirow{2}{*}{ CCPMG } & 6-FAM & $197-297$ & PMGF & tgattcacgtctattgecac \\
\hline & & & PMGR & gttaa gttctcggtgaatcg \\
\hline COL6 & 6-FAM & $260-270$ & $\begin{array}{l}\text { COLEF } \\
\text { COLER }\end{array}$ & $\begin{array}{l}\text { ggcagggcagaggta aøcag } \\
\text { gctagagagtcaaca tgatgtg }\end{array}$ \\
\hline \multirow[t]{2}{*}{ COL7 } & VIC & $173-174$ & COL7F & gaaccccgactacgtgattatc \\
\hline & & & COL7R & tggcactatatcaccatcactg \\
\hline \multirow[t]{2}{*}{ COL11 } & VIC & $258-267$ & COL11F & ctcatgegtccctgcatgcgac \\
\hline & & & COL11R & gtggcactaccagaacatacag \\
\hline \multirow[t]{2}{*}{ SA1 } & NED & $300-320$ & SA1F & 8gatcaccaccacta g g gtcc \\
\hline & & & SA1R & gtgtctecgtaa cgcagtggt \\
\hline \multirow[t]{2}{*}{ SA3 } & 6-FAM & $200-215$ & $\mathrm{SA} 3 \mathrm{~F}$ & tcaccaccactggcgtccagac \\
\hline & & & SA3R & tcgttatcttggtgactgtaga \\
\hline \multirow[t]{2}{*}{ SA4 } & PET & $150-200$ & SA4F & cagagcatgagatgaatagat g \\
\hline & & & SA4R & agtcaggctcttcacgctctgt \\
\hline SAG & PET & $209-221,316-365$ & $\begin{array}{l}\text { SAGF } \\
\text { SAGR }\end{array}$ & $\begin{array}{l}\text { atcgacgatcaggttctggatc } \\
\text { tattgeggtaacocaattitcg. }\end{array}$ \\
\hline$S A 9^{b}$ & NED & $190-200,203-215$ & SA9F & getcgegctgecaatccttaag \\
\hline
\end{tabular}


The computer programme MultiLocus 1.3b (Agapow \& Burt 2001) was used for all allelic analyses. The population differentiation $(\theta)$ (Weir \& Cockerham 1984) and theoretical number of migrants per generation $\widehat{\widehat{M}}=1 / 2\left(\frac{1}{\sigma}-1\right.$ (Slatkin 1995) were estimated between a population of $C$. cubensis isolates from South America, from which the type of $C$. cubensis originates (Bruner 1917), and a population of the known species C. austroafricana. This was used as the expected statistic in further analyses, since the species represented by these populations are well defined. Pair wise $\theta$-values were then calculated in all combinations between isolates representing the two clades of C. cubensis and C. austroafricana.

The significance of equality or positive deviation from the expected differentiation value was determined using a one-tailed G-test (Sokal and Rohlf 1994), which is the ML statistical significance of deviation,

$G=2 \sum_{i} O_{i} \cdot \ln \left(\frac{O_{i}}{E_{i}}\right)$

where $\mathrm{G}$ is the ML estimator, $\mathrm{O}$ is the observed value, and $\mathrm{E}$ is the expected value. The distribution of $\mathrm{G}$ is approximately that of $\chi^{2}$, with the same degrees of freedom. Thus, if isolates representing the Southeast Asian clade of $C$. cubensis represent a distinct species, they should display population differentiation values that are equal to or higher than those obtained between the populations representing C. cubensis from South America and C. austroafricana. However, if G-test values were significantly lower than expected, the null hypothesis of equal or higher levels of differentiation could be rejected.

Population differentiation was further explored using the programme Structure 2.3.1 (Pritchard et al. 2000). Allelic data were subjected to an assignment test with the origin of an isolate dictating the prior to the Markov Chain analysis. Therefore, three populations, i.e., C. austroafricana and the two clades of $C$. cubensis, were used as priors. The run length was 1100000 with a burnin of 100000 iterations. After analysis, the assignments were visualized using a bar plot constrained by the population priors, and a triangle plot to visualize possible admixture between populations. These plots depicted the estimated membership coefficients for each individual to each population prior (q) in two different ways (Pritchard et al. 2000). In the bar plot, each individual was represented by a vertical bar partitioned into $\mathrm{K}$ population priors that indicated the estimated membership of that individual to each prior. The triangle plot depicted Q, the probability of an individual's ancestry from population prior q, where each individual was indicated with a dot and the distance of the dot from each of the triangle's edges was proportionate to the ancestry vectors for the individual. Therefore, each of the individuals in this analysis would have had $\mathrm{K}=3$ ancestry vectors adding up to 1 .

\section{Morphology}

In order to characterise and compare the morphology of representative specimens of the two clades of Chrysoporthe cubensis, dried herbarium specimens of C. cubensis sensu lato bearing fruiting structures (Gryzenhout et al. 2004) were reexamined microscopically. Some of these specimens are linked to isolates in the two subclades (Gryzenhout et al. 2004). Fruiting structures were mounted in Leica mountant (Setpoint Premier, South Africa) and sectioned at 12-16 $\mu \mathrm{m}$ using a Leica CM1100 cryostat (Setpoint Premier). Sections were mounted in lactophenol and examined using light microscopy and the measurement software Axiovision 4.8 (Carl Zeiss, GmbH). Fifty asci, ascospores, conidiophores and conidia were measured for each specimen, and a range was obtained for ascostromata and conidiomata. Measurements were represented as (minimum-) (mean-SD) $($ mean $+\mathrm{SD})(-$ maximum) where SD is the standard deviation. 


\section{Results}

\section{Phylogenetic analyses}

After sequencing and alignment of four gene regions from each isolate (Table 1), alignment lengths ranged from $273 \mathrm{bp}$ for ACT to $830 \mathrm{bp}$ for the two $\beta$-tubulin regions. The total alignment length when gene regions were combined was 1914 characters. These alignments are available in TreeBase (SN4622).

Sequence alignments revealed 13 fixed nucleotide polymorphisms across all gene regions that differentiate isolates representing the Southeast Asian clade of Chrysoporthe cubensis from the South American clade and Chrysoporthe austroafricana (Table 3). Three nucleotide polymorphisms in the $\beta$-tubulin gene differentiated Southeast Asian $C$. cubensis from the others, while three polymorphisms across the four genes were diagnostic for South American C. cubensis. Similarly, six polymorphisms across the four genes were characteristic of $C$. austroafricana. Therefore, these fixed nucleotide differences are diagnostic for the different species, either in combination or singly in the case of private polymorphisms.

Table 3. Nucleotide polymorphisms ${ }^{\mathrm{a}}$ associated with C. austroafricana, C. cubensis (South American clade) and C. deuterocubensis (Southeast Asian clade).

\begin{tabular}{|c|c|c|c|c|c|c|c|c|c|c|c|c|c|c|c|c|c|}
\hline \multirow[t]{3}{*}{ Species } & \multirow[t]{3}{*}{ Isolate } & \multirow[t]{3}{*}{ ACT } & \multicolumn{10}{|c|}{ p-tubulin } & \multirow[t]{3}{*}{$E F-1 \alpha$} & \multicolumn{4}{|c|}{ ITS } \\
\hline & & & \multicolumn{10}{|l|}{$\cdot$} & & \multicolumn{4}{|c|}{$\cdot$} \\
\hline & & & & & & 1 & 1 & 1 & 1 & 1 & 1 & 1 & & 2 & 2 & 2 & 2 \\
\hline & & 4 & 5 & 6 & 7 & 4 & 4 & 4 & 4 & 4 & 5 & 5 & 4 & 1 & 1 & 2 & 2 \\
\hline & & 7 & 5 & 9 & 2 & 7 & 8 & 9 & 9 & 9 & 5 & 7 & 1 & 0 & 7 & 0 & 1 \\
\hline & & 5 & 0 & 9 & 9 & 7 & 8 & 0 & 3 & 9 & 4 & 2 & 8 & 7 & 8 & 5 & 0 \\
\hline \multirow[t]{2}{*}{ C. austroafricana } & CMW9327 & G & $\mathrm{T}$ & C & C & C & G & C & C & C & C & C & A & $\mathrm{T}$ & A & - & A \\
\hline & CMW10192 & G & $\mathrm{T}$ & C & C & C & G & C & C & C & C & C & A & $\mathrm{T}$ & A & - & A \\
\hline \multirow[t]{4}{*}{ C. cubensis } & CMW10028 & A & $\mathrm{T}$ & C & C & $\mathrm{T}$ & A & A & A & $\mathrm{T}$ & $\mathrm{T}$ & $\mathrm{T}$ & C & C & A & - & A \\
\hline & CMW10669 & A & $\mathrm{T}$ & C & C & $\mathrm{T}$ & A & A & A & $\mathrm{T}$ & $\mathrm{T}$ & $\mathrm{T}$ & C & C & A & - & A \\
\hline & CMW10778 & A & $\mathrm{T}$ & C & C & $\mathrm{T}$ & A & A & A & $\mathrm{T}$ & $\mathrm{T}$ & $\mathrm{T}$ & C & C & A & - & A \\
\hline & CMW12734 & A & $\mathrm{T}$ & C & C & $\mathrm{T}$ & A & A & A & $\mathbf{T}$ & $\mathrm{T}$ & $\mathrm{T}$ & C & C & A & - & A \\
\hline \multirow[t]{4}{*}{ C. deuterocubensis } & CMW2631 & G & C & $\mathrm{T}$ & $\mathrm{T}$ & C & G & A & A & $\mathrm{T}$ & $\mathrm{T}$ & C & C & C & G & $\mathrm{T}$ & G \\
\hline & CMWB650 & G & C & $\mathrm{T}$ & $\mathrm{T}$ & C & G & A & A & $\mathrm{T}$ & $\mathrm{T}$ & C & C & C & G & $\mathrm{T}$ & G \\
\hline & CMW12745 & G & C & $\mathrm{T}$ & $\mathrm{T}$ & C & G & A & A & $\mathrm{T}$ & $\mathrm{T}$ & C & C & $\mathrm{C}$ & G & $\mathrm{T}$ & G \\
\hline & CMW17178 & G & C & $\mathrm{T}$ & $\mathrm{T}$ & C & G & A & A & $\mathrm{T}$ & $\mathrm{T}$ & C & C & C & G & $\mathrm{T}$ & G \\
\hline \multicolumn{2}{|c|}{ Unfixed polymorphisms } & 2 & 2 & & & & & & & & & & 5 & 11 & & & \\
\hline
\end{tabular}

a Nucleotide positions are relative to the start codon of the corresponding gene from Neurospora crassa or (") alignment positions due to a corresponding gapin the N.crassa sequence. Shaded nucleotides differentiate C. deuterocubens is (Southeast Asian cla de) from C. austroafricana and C. cubensis (South American clade), while nucleotides in bold were exploited in a PCR-RFLP diagnostic technique.

A partition homogeneity test revealed that all the DNA regions used in this study could be combined $(\mathrm{P}=0.001)$ (Cummings et al. 1995). Inspection of the g1 statistic for each of the four gene regions, as well as the combined data set, revealed that all data sets contained useful phylogenetic signal ( $\mathrm{P}$ $=0.01$ ) (Fig 1). ML analysis of individual gene regions mostly recovered the two clades of $C$. cubensis as separate (Fig 1). Southeast Asian C. cubensis isolates formed a separate clade in the $\beta$ tubulin and ITS gene genealogies (Fig 1B and D). However, in the EF-1 $\alpha$ genealogy, the Southeast Asian and South American C. cubensis were difficult to distinguish because they were present in the same clade with no bootstrap-supported partitions (Fig 1C). The ACT genealogy (Fig 1A) did not distinguish between Southeast Asian C. cubensis and Chrysoporthe inopina. ML analysis of the combined information for the four regions sequenced (Fig 1E) recovered two well-supported and separate clades for the Southeast Asian and South American C. cubensis isolates. Using these analyses, isolates representing the South American clade of $C$. cubensis were more closely related to C. austroafricana than to isolates in the Southeast Asian clade. 
(A) $(275 ; 6 ;-1.029)$

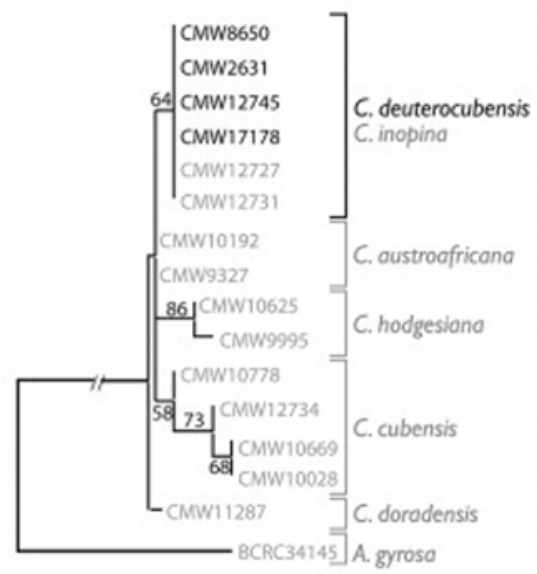

(C)

$(327 ; 11 ;-0.948)$

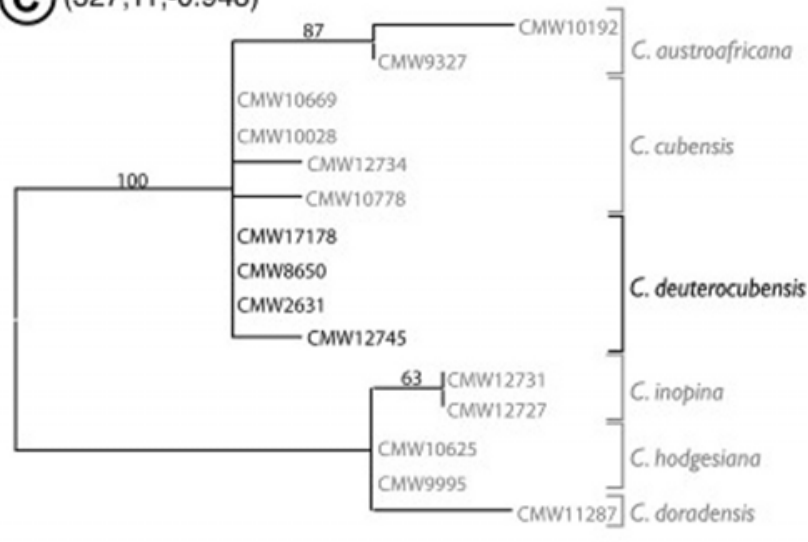

(D) $(490 ; 6 ;-0.584)$

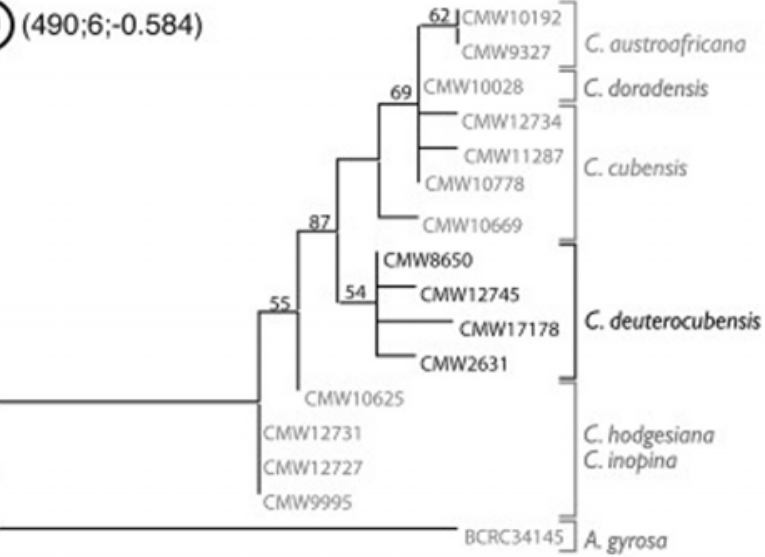

(B) $(830 ; 23 ;-0.728)$

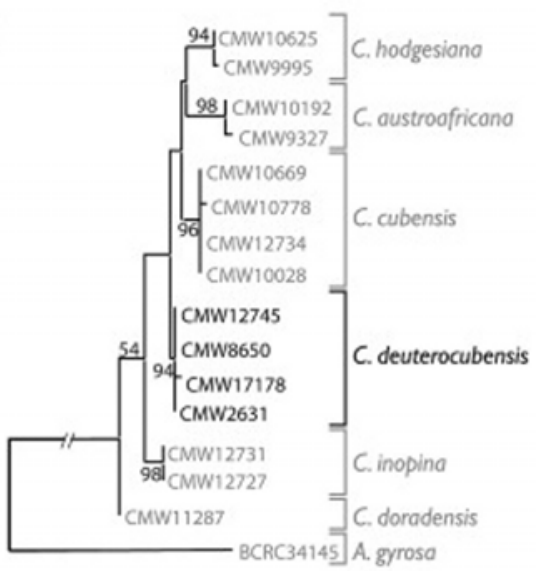

(E) $(1914 ; 53 ;-0.921)$

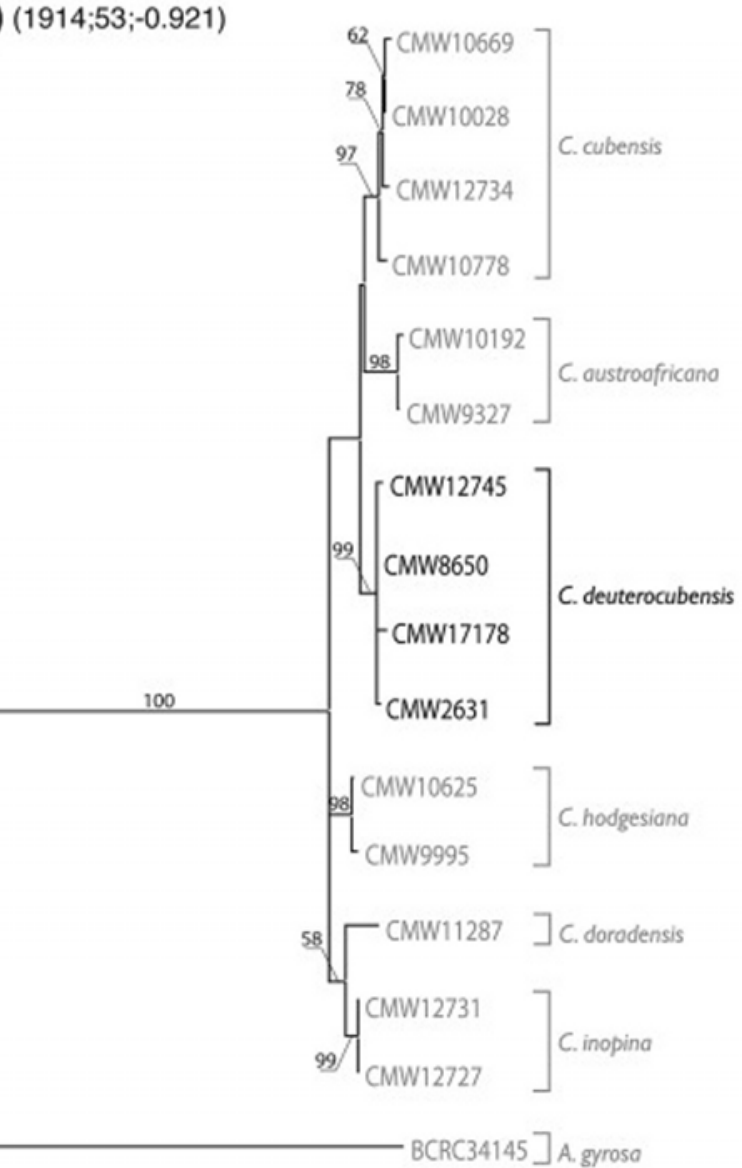

Fig 1. ML phylogenies obtained from (A) ACT, (B) $\beta$-tubulin (BT1 and BT2 regions), (C) elongation factor 1- $\alpha$, and (D) ITS gene sequences. (E) The multilocus phylogeny when all genes were combined and analyzed with ML (C) was midpoint rooted, while the other phylogenies were rooted with Amphilogia gyrosa. Bootstrap values above $50 \%$ (1000 replicates) are indicated above each branch. For each genealogy, relevant tree statistics are indicated in parentheses in the order: alignment length in base pairs; number of parsimony-informative characters; g1 statistic (Hillis \& Huelsenbeck 1992) at a significance level of $\mathrm{P}=0.01$.

\section{Population differentiation analysis}

Differentiation between Chrysoporthe austroafricana and South American Chrysoporthe cubensis populations (i.e., the expected level of differentiation between two distinct species), was 0.30 (Fig 2C). Analyses using a G-test showed that there were no significant differences $(\mathrm{P}<0.05)$ in the levels of differentiation among the three populations. It was thus possible to reject the null hypothesis that these populations are not significantly different, because the theoretical number of 
migrants per generation (

$\widehat{M}$; calculated from the $\theta$ value) between the different populations were comparable and similar

levels of differentiation were observed among them. Similarly, the results of population assignment tests suggested that populations of $C$. austroafricana and South American and Southeast Asian $C$. cubensis can be readily separated (Fig $2 \mathrm{~A}$ and B). These data highlighted the fact that the three populations were each characterized by markedly different allelic compositions, although a low level of admixture was detected (Fig 2A, Table 4). However, the genetic distance between the two populations of $C$. cubensis was comparable to those between the $C$. austroafricana population and the respective C. cubensis populations (Fig 2B). This was evident from the reciprocal presence of alleles and nearly identical ancestry vectors for all three populations.
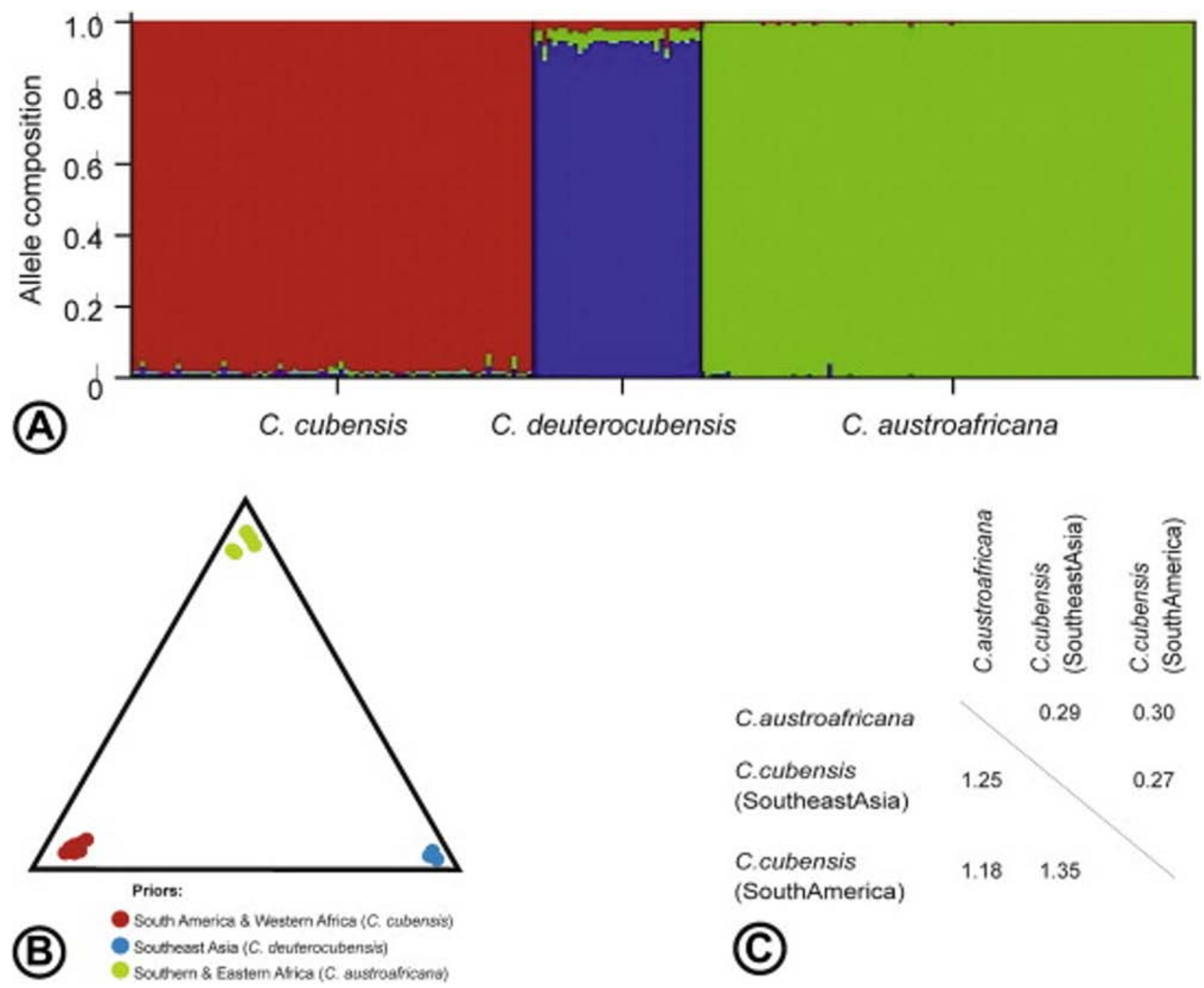

Fig 2. Population assignment and gene flow statistics for the Chrysoporthe austroafricana (green; southern and western Africa), C. cubensis (red; South America) and C. deuterocubensis (blue; Southeast Asia) genotypes observed in this study. (A) Visualization of population assignment tests for allelic data and (B) a bar plot displaying individuals (X-axis) and the percentage of alleles from each of the priors that each individual possesses (Y-axis), as revealed by structure. (C) Population differentiation values $(\theta)$ and the estimated numbers of migrants per generation View the MathML source appear above and below the diagonal, respectively, and show the general absence of genotype admixture between species. 
Table 4. Allele frequency distributions expressed as Nei's gene (allele) diversity (Nei 1973) per locus and per species, in representative populations of Chrysoporthe austroafricana, C. cubensis and $C$. deuterocubensis.

\begin{tabular}{|c|c|c|c|c|c|c|c|c|c|c|c|c|c|c|}
\hline & $\begin{array}{c}\text { Number of } \\
\text { isolates }\end{array}$ & CCFMC & CcPMG & COL6 & COL7 & COL11 & SA1 & $\mathrm{SA} 3$ & SA4 & SA6-1 & SA6-2 & SA9-1 & SA9-2 & $\overline{H^{2}}$ \\
\hline $\begin{array}{l}\text { Chrysoparthe } \\
\text { aus troafrican a }\end{array}$ & 97 & 0.7782 & 0.2368 & 0.5029 & 0.0204 & 0.3119 & 0.3700 & 0.7397 & 0.6862 & 0.2610 & 0 & 0.1911 & 0.6791 & 0.3981 \\
\hline $\begin{array}{l}\text { Chrysoparthe } \\
\text { cubensis }\end{array}$ & 79 & 0.7713 & 0.0496 & 0.5435 & 0 & 0.1647 & 0.0759 & 0.4995 & 0.5188 & 0.7152 & 0.0251 & 0.2279 & 0.4619 & 0.3379 \\
\hline $\begin{array}{l}\text { Chrysoparthe } \\
\text { deuterocubensis }\end{array}$ & 33 & 0.3177 & 0.1140 & 0.7907 & 0.2187 & 0.3801 & 0.5933 & 0.5951 & 0.4115 & 0.7400 & 0 & 0.4628 & 0.5841 & 0.4340 \\
\hline
\end{tabular}

a $\bar{H}$ is the average gene (allele) diversity for a population over all loci.

\section{Taxonomy}

Phylogenetic and population genetic analyses in this study have provided robust justification to treat the Southeast Asian and South American isolates of Chrysoporthe cubensis as distinct taxa. Chrysoporthe cubensis was first described from Cuba (Bruner 1917) and this name should be reserved for South American isolates related to those from Cuba. Gryzenhout et al. (2006a) designated an epitype for C. cubensis based on an isolate from Cuba and residing in the South American clade of the fungus. Isolates representing the Southeast Asian clade represent a distinct taxon described as follows:

Chrysoporthe deuterocubensis Gryzenh \& M.J. Wingf., sp. nov. MycoBank No.: MB516634 Fig 3.

Etymology: The name reflects the fact that the fungus is different yet closely related to Chrysoporthe cubensis.

Ascospores (5.5-)6.5-7.5(-8) $\times 2-2.5(-3) \mu \mathrm{m}$; conidiomata subaurantiaca, brunnea Siennae vel atrofusca, pyriformia, clavata vel pulvinata; conidia $(3-) 3.5-4.5(-5) \times(1.5) 2(-2.5) \mu \mathrm{m}$; position actinis $475(\mathrm{G}, \mathrm{A})$; positions $\beta$-tubulinis $546(\mathrm{C}, \mathrm{T}), 699$ (T, C) $729(\mathrm{~T}, \mathrm{C}), 1477(\mathrm{C}, \mathrm{T}), 1488(\mathrm{G}, \mathrm{A})$, 1572 (C, T) (TreeBase SN4622); sitibus exceptionis pro AvaI, fragmenta 87 bp, 113 bp, et 337 bp ferentibus, et uno pro HindIII fragmenta $206 \mathrm{bp}$ et $331 \mathrm{bp}$ ferenti.

Ascospores (5.5-)6.5-7.5(-8) $\times 2-2.5(-3) \mu \mathrm{m}$; conidiomata sienna to almost orange to fuscousblack, pyriform to clavate to pulvinate; conidia $(3-) 3.5-4.5(-5) \times(1.5-) 2(-2.5) \mu \mathrm{m}$; ACT position 475 (G, A); ß-tubulin positions 546 (C, T), 699 (T, C) 729 (T, C), 1477 (C, T), 1488 (G, A), 1572 $(\mathrm{C}, \mathrm{T})$ (TreeBase SN4622). Two restriction sites for AvaI, yielding fragments of $87 \mathrm{bp}, 113 \mathrm{bp}$, and $337 \mathrm{bp}$, and one restriction site for HindIII, yielding fragments of $206 \mathrm{bp}$ and $331 \mathrm{bp}$.

Ascostromata semiimmersed erumpent, top of perithecial bases covered with cinnamon to orange, predominantly prosenchymatous, limited stromatic tissue, ascostroma 120-230 $\mu \mathrm{m}$ high above level of bark, 280-490 $\mu \mathrm{m}$ diam., perithecia valsoid, bases immersed in bark, fuscous-black, extending necks up to $240 \mu \mathrm{m}$ long emerging through bark covered in umber stromatic tissue of textura porrecta, appearing fuscous-black. Asci $(19-) 22-26.5(-28) \times(4.5-) 5-6.5(-7) \mu \mathrm{m}$, fusoid to ellipsoidal, 8-spored. Ascospores (5.5-)6.5-7.5(-8) $\times 2-2.5(-3) \mu \mathrm{m}$, hyaline, 1 -septate, fusoid to oval, ends tapered, with septum variously placed in the spore but usually central. 

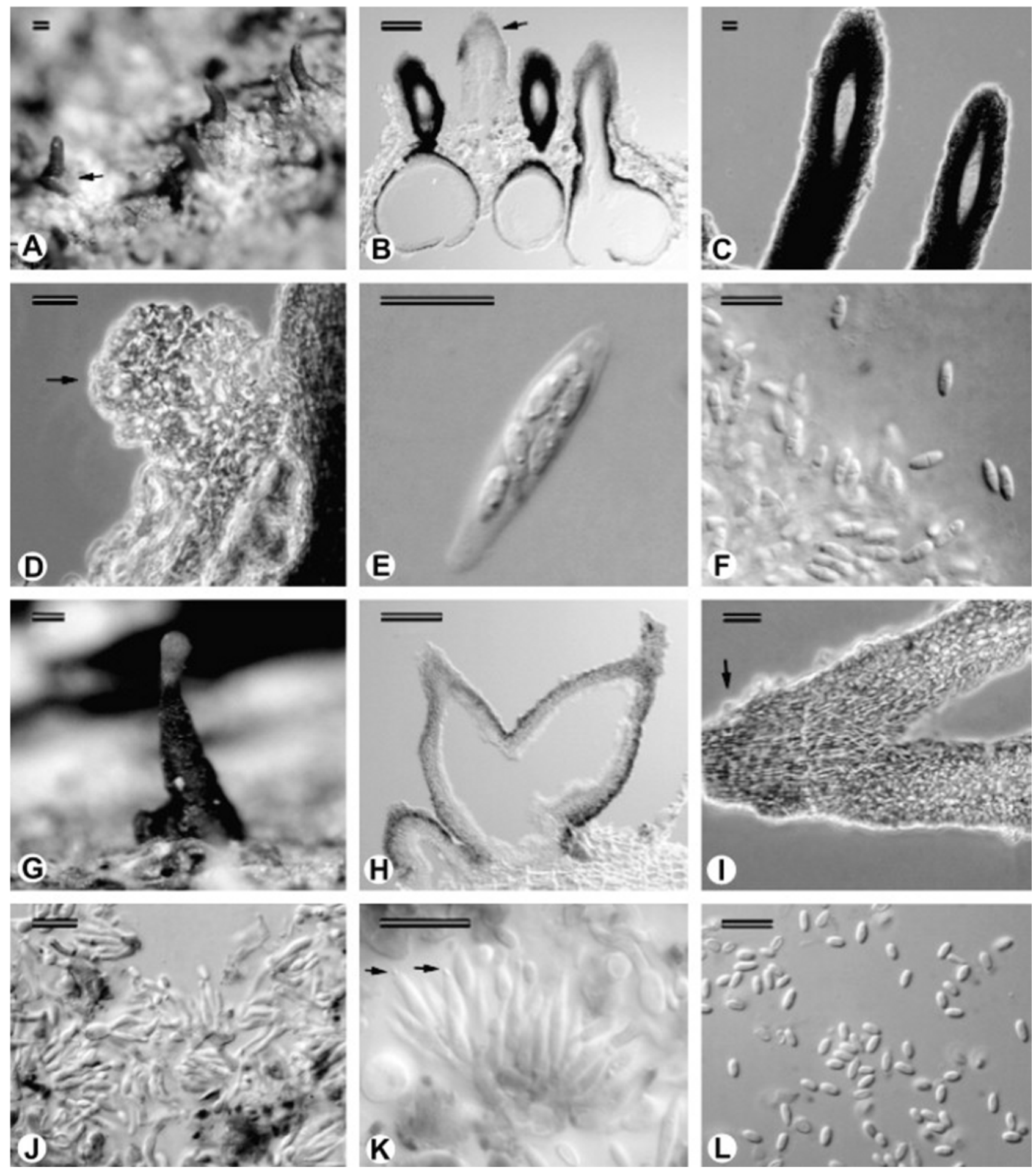

Fig 3. Fruiting structures of Chrysoporthe deuterocubensis. (A) Ascostromata on bark (arrow indicates stromatic tissue). (B) Longitudinal section through ascostroma. (C) Black perithecial necks covered with stromatic tissue. (D) Prosenchymatous stromatic tissue (arrow) of ascostroma. (E) Ascus. (F) Ascospores. (G) Conidioma on bark. (H) Vertical section through conidiomata. (I) Tissue of textura globulosa for the conidiomal base and of textura porrecta for the neck (arrow). (JK) Conidiophores. (L) Conidia. Scale bars A-B, G-H $=100 \mu \mathrm{m}$; C-D, I = $20 \mu \mathrm{m}$; E-F, J-L = 10 $\mu \mathrm{m}$.

Conidiomata occurring on the surface of the ascostroma or as separate structures, superficial to slightly immersed, sienna to almost orange to fuscous-black, with an umber interior when young, pyriform to clavate, sometimes pulvinate, with one to four attenuated necks per structure, conidiomatal base above the bark surface 130-740 $\mu \mathrm{m}$ high, 100-950 $\mu \mathrm{m}$ diam, necks up to $230 \mu \mathrm{m}$ long, 90-240 $\mu \mathrm{m}$ wide. Conidiomatal locules with even to convoluted inner surface, occasionally 
multilocular, single locule connected to one or several necks. Stromatic tissue at base of textura globulosa with walls of outer cells thickened, neck cells of textura porrecta. Conidiophores hyaline, with globose to rectangular basal cells that are $(2.5-) 4-7(-8.5) \times(2-) 3-4.5(-5.5) \mu \mathrm{m}$, branched irregularly at the base or above into cylindrical cells, cells delimited by septa or not, total length of conidiophore (12-)13.5-19(-24.5) $\mu \mathrm{m}$, conidiogenous cells cylindrical to flask-shaped with attenuated apices, $(1.5-) 2-2.5(-3) \mu \mathrm{m}$ wide. Conidia $(3-) 3.5-4.5(-5) \times(1.5-) 2(-2.5) \mu \mathrm{m}$, hyaline, oblong, aseptate, exuded as bright luteous tendrils or droplets.

Cultures white with cinnamon to hazel patches on malt extract agar, fluffy, margin smooth, fastgrowing, covering a $90 \mathrm{~mm}$ diam plate after a minimum of $5 \mathrm{~d}$ at the optimum temperature of $30{ }^{\circ} \mathrm{C}$ (Gryzenhout et al. 2004).

The following nucleotide characters are differentially fixed for $C$. deuterocubensis (given as the gene name, the nucleotide position relative to the start codon of the corresponding aligned gene for Neurospora crassa, and in parentheses, the nucleotides fixed for $C$. deuterocubensis and $C$.

cubensis, respectively): ACT position $475(\mathrm{G}, \mathrm{A})$; $\beta$-tubulin positions $546(\mathrm{C}, \mathrm{T}), 699(\mathrm{~T}, \mathrm{C}) 729(\mathrm{~T}$, C), 1477 (C, T), $1488(\mathrm{G}, \mathrm{A}), 1572(\mathrm{C}, \mathrm{T})$ (TreeBase SN4622). Additionally, the Bt1 region of the $\beta$ tubulin gene of $C$. deuterocubensis, amplified using primers Bt1a and Bt1b (Glass \& Donaldson 1995), contains two restriction sites for AvaI, yielding fragments of $87 \mathrm{bp}, 113 \mathrm{bp}$, and $337 \mathrm{bp}$, and one restriction site for HindIII, yielding fragments of $206 \mathrm{bp}$ and $331 \mathrm{bp}$.

\section{Specimens examined}

INDONESIA, Sumatra, Lake Toba, Melastoma malabathricum, May 2005, M.J. Wingfield, holotype PREM 58799, living extype culture CMW $18515=$ CBS 118651 shown to group in the Southeast Asian clade (Gryzenhout et al. 2006a), Lake Toba, Aek Nauli, M. malabathricum, Feb. 2004, M.J. Wingfield, PREM 58798, living culture CMW 16192 = CBS 119474; Sulawesi, Syzygium aromaticum, 2001, M.J. Wingfield, PREM 57470, cultures CMW 8650 = CBS 115719, CMW 8651 = CBS 115718; Sulawesi, S. aromaticum, 2003, M.J. Wingfield, PREM 58018, PREM 58019; Sulawesi, Utard, S. aromaticum, 2003, M.J. Wingfield, PREM 58020; Bankals, Selindung, Eugenia sp., C.P.A. Bennett, IMI 231648; Sumatra, Kurai, Taji, Eugenia sp., C.P.A. Bennett, IMI 231649; Sumatra, Eucalyptus sp., 2001, M.J. Wingfield, PREM 57297, cultures from the same area CMW 11288 = CBS 115736, CMW 11289 = CBS 115737, CMW 11290 = CBS 115738; Sumatra, Sei Kabaro, Eucalyptus sp., 2001, M.J. Wingfield, PREM 58021, cultures from same area CMW 11289, CMW 11290. MALAYSIA, Johar, Kluang, Eucalyptus aromatica, 1986, Loh Chow Fong, IMI 304273; Serdang, Fe. Exp. Stn., S. aromaticum (as Eugenia caryophyllata), 1954, A. Johnston, IMI 58569; Eugenia sp., 1954, A. Johnston, IMI 58567, IMI 58568; Jelok Bahang, S. aromaticum (as E. caryophyllata), 1954, A. Johnston, IMI 58388. SINGAPORE, Istana grounds, S. aromaticum, 1991, C.P. Yik, dried culture IMI 350626; Tibouchina urvilleana, April 2003, M.J. Wingfield, PREM 58797, living culture CMW 12745 = CBS 117837.

\section{Distribution}

Countries where the identity has been confirmed based on DNA sequence comparisons: U.S.A. (Hawaii), Tanzania (Zanzibar), Kenya, Malawi, Mozambique, Indonesia, Singapore, Thailand, China (Hong Kong-ITS only), Australia (Myburg et al. 1999a; Myburg et al. 2003; Roux et al. 2003; Gryzenhout et al. 2004; Gryzenhout et al. 2006b; Nakabonge et al. 2006). Isolates from Vietnam, although previously reported as C. cubensis (Old et al. 2003), are also shown for the first time to represent $C$. deuterocubensis based on DNA sequence data. Chrysoporthe cubensis sensu lato reported from India, Malaysia and Western Samoa (Hodges et al. 1979; Sharma et al. 1985; Hodges et al. 1986; Old et al. 2003) most likely also reside in C. deuterocubensis although sequence data for these isolates are not available. 


\section{Restriction enzyme-based DNA diagnostic}

To facilitate routine differentiation among Chrysoporthe cubensis, Chrysoporthe deuterocubensis and Chrysoporthe austroafricana, the $\beta$-tubulin Bt1 region was subjected to PCR-RFLP (restriction fragment length polymorphism) analysis. For this purpose we used two restriction enzymes AvaI and HindIII. Separate digests with these enzymes revealed that $C$. austroafricana, $C$. cubensis and C. deuterocubensis could easily be distinguished from each other (Fig 4). When AvaI was used, three bands (87 bp, $113 \mathrm{bp}$ and $337 \mathrm{bp}$ ) were observed for $C$. austroafricana and $C$.

deuterocubensis, while two bands ( $87 \mathrm{bp}$ and $440 \mathrm{bp}$ ) were observed for $C$. cubensis. Therefore, this enzyme could distinguish $C$. cubensis from $C$. austroafricana and $C$. deuterocubensis. In contrast, HindIII did not cut for $C$. austroafricana but produced two fragments (206 bp and $331 \mathrm{bp}$ ) for each of the other two species. Therefore, HindIII could distinguish C. austroafricana from C. cubensis and $C$. deuterocubensis.

In order to test the robustness of this new identification technique, 400 putative isolates of $C$. austroafricana, C. cubensis and C. deuterocubensis were obtained from the CMW collection at FABI (Table 5). Isolates were randomized, renumbered and subjected to a blind test using the $\beta$ tubulin PCR-RFLP technique. After obtaining the restriction profile for each isolate, it was given a putative species name and compared to the place of origin recorded for that isolate number in the culture collection. All isolates from South Africa were identified as C. austroafricana, while $C$. cubensis isolates originated from South America and C. deuterocubensis isolates originated from Southeast Asia.

\section{Discussion}

Results of this study have shown that isolates representing the South American and Southeast Asian clades of Chrysoporthe cubensis represent distinct species. Those residing in the Southeast Asian clade have consequently been provided with the name Chrysoporthe deuterocubensis. Recognition of these two taxa as distinct species is supported by phylogenetic analyses of sequences for four variable gene regions that separated representative isolates of the two species. Both species are also associated with a number of differentially fixed polymorphisms in the five regions examined. Populations linked to these two species from different geographic regions also showed significant differentiation from each other as their distributions do not overlap.

Based on morphology, C. cubensis and C. deuterocubensis are virtually indistinguishable (Gryzenhout et al. 2004) and perceived differences are usually variable or due to environmental conditions (Gryzenhout et al. 2009). However, the sienna to sometimes orange colour of especially young conidiomata observed in some $C$. deuterocubensis specimens is not common in $C$. cubensis, although mature conidiomata are usually similar in appearance. An alternative and robust approach to distinguish the species is to use variation in the gene encoding $\beta$-tubulin, which can either be evaluated directly through sequencing or using the PCR-RFLP procedure described in this study. The latter approach is rapid and will be useful for quarantine purposes where a simple diagnostic is typically required. 

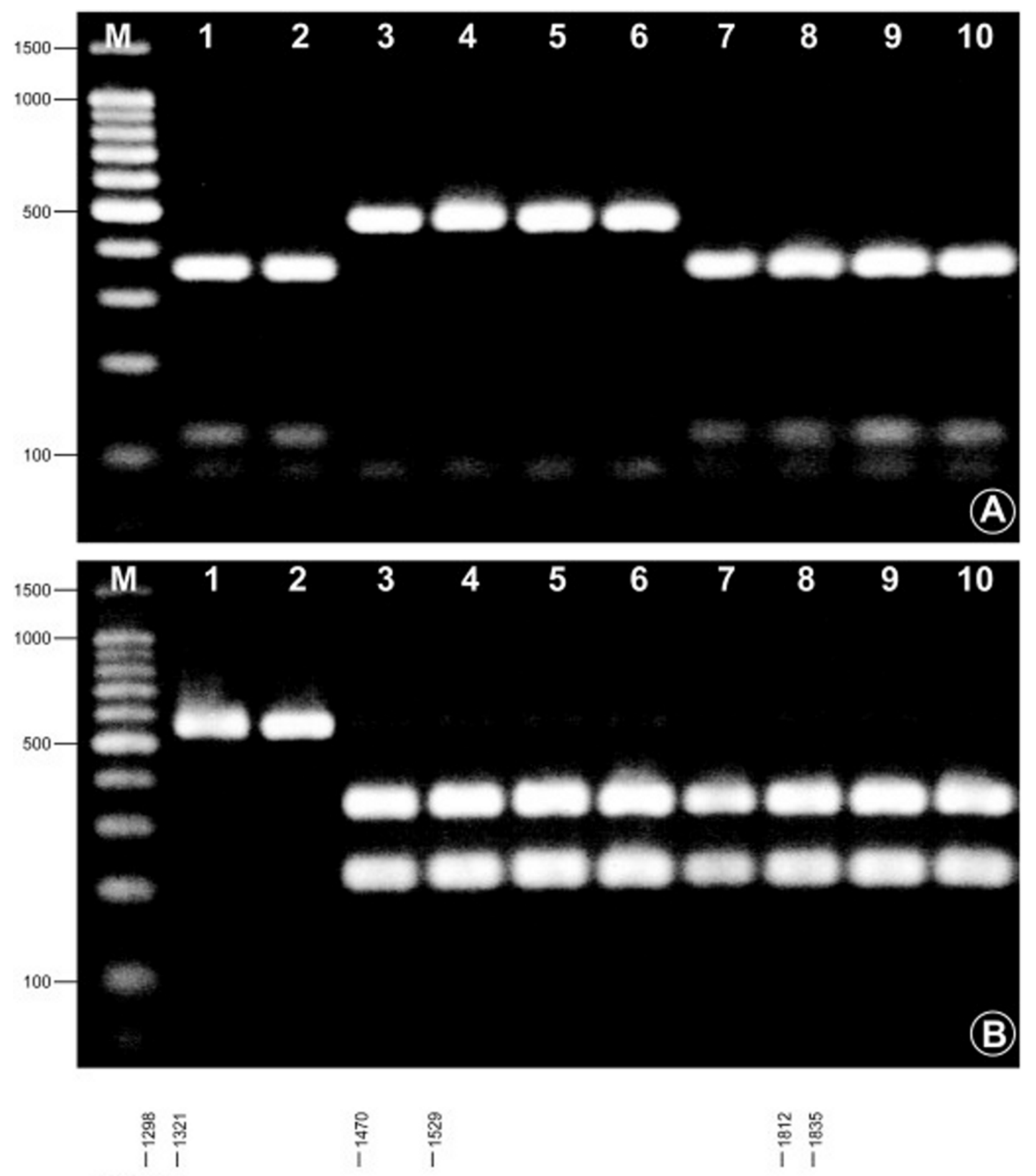

Bt1a $\longrightarrow$

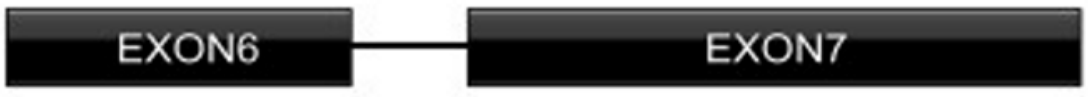

(C)

$\longleftarrow$ Bt1b

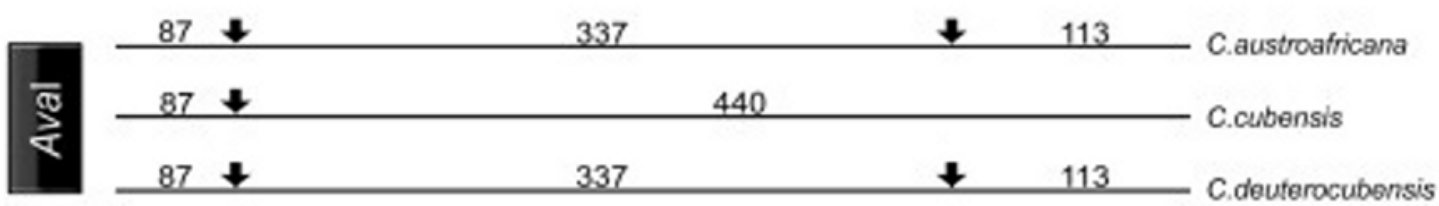

537

C.austroafricana

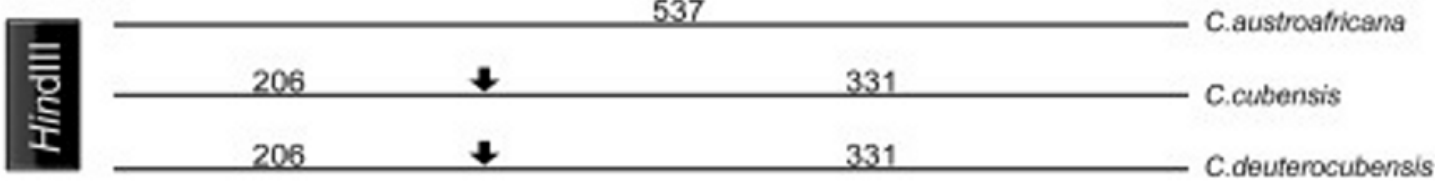


Fig 4. Digests of $\beta$-tubulin gene PCR products (primers Bt1a to Bt1b) for C. austroafricana (lanes 1 and 2), C. cubensis (lanes 3-6) and C. deuterocubensis (lanes 7-10). Lane 1, CMW9327; 2, CMW10192; 3, CMW10028; 4, CMW10669; 5, CMW10778; 6, CMW12734; 7, CMW2631; 8, CMW8650; 9, CMW12745; 10, CMW17178. Lane M is a 100 bp DNA ladder. (A) Restriction profile using AluI; (B) restriction profile using HindIII; (C) restriction maps showing restriction site differences between the three fungal species. The gene map displays coding sequence as grey boxes and intron sequence as a solid line. Primer positions are indicated with arrows on opposite strands of the expected amplicon of $537 \mathrm{bp}$. Position numbers start at 1 for the first coding base of the Bml gene for Neurospora crassa (Glass \& Donaldson 1995).

Table 5. Results from a blind PCR-RFLP test showing nonoverlapping distributions for the three species of Chrysoporthe.

\begin{tabular}{|c|c|c|c|c|}
\hline $\begin{array}{l}\text { Continent } \\
\text { of origin }\end{array}$ & Country of origin & Host species & Number of isolates & Assigned species name \\
\hline \multirow[t]{10}{*}{ Africa } & $\begin{array}{l}\text { Democratic Republic } \\
\text { of Congo }\end{array}$ & Eucalyptus sp. & 12 & Chrysoparthe cubensis \\
\hline & \multirow[t]{3}{*}{ South Africa } & Eucalyptus grandis & 39 & \multirow[t]{7}{*}{ Chrysoparthe austroafricana } \\
\hline & & Syzygium sp. & 47 & \\
\hline & & Tbouchina sp. & 22 & \\
\hline & \multirow[t]{2}{*}{ Malawi } & Eucalyptus sp. & 1 & \\
\hline & & Syzygium cordatum & 2 & \\
\hline & \multirow[t]{2}{*}{ Mozambique } & Eucalyptus saligna & 11 & \\
\hline & & Syzygiom cordatum & 21 & \\
\hline & Tanzania & Eugenia cariophillus & 1 & \multirow{2}{*}{$\begin{array}{l}\text { Chrysoparthe deuterocubensis } \\
\text { Chrysoparthe austroafricana }\end{array}$} \\
\hline & Zambia & Eucalyptus sp. & 11 & \\
\hline Australia & Australia & Eucalyptus sp. & 1 & Chrysoparthe deuterocubensis \\
\hline \multirow[t]{7}{*}{ South America } & Brazil & Eucalyptus sp. & 20 & \multirow[t]{7}{*}{ Chrysoparthe cubensis } \\
\hline & \multirow[t]{2}{*}{ Colombia } & Eucalyptus sp. & 46 & \\
\hline & & $\begin{array}{l}\text { Vaccinium fioribundum } \\
\text { (Mortiño) }\end{array}$ & 38 & \\
\hline & Cuba & Eucalyptus sp. & 25 & \\
\hline & Hawaï & & 17 & \\
\hline & Mexico & & 32 & \\
\hline & Venezuela & & 13 & \\
\hline \multirow[t]{3}{*}{ Southeast Asia } & Indonesia & Eucalyptus grandis & 23 & \multirow[t]{3}{*}{ Chrysoparthe deuterocubensis } \\
\hline & & Eugenia aromatica & 1 & \\
\hline & Vietnam & Eucalyptus sp. & 17 & \\
\hline
\end{tabular}

The multigene phylogeny presented in this study showed clear separation of $C$. deuterocubensis from C. cubensis (Fig 1). However, analyses of the individual regions suggested that the EF-1 $\alpha$ region is not sufficiently variable to allow separation of $C$. deuterocubensis from C. cubensis (Fig 1C). This was also true for the ACT sequences that did not allow separation of $C$. deuterocubensis and Chrysoporthe inopina (Fig 1A). This is probably due to the relatively recent divergence of species in Chrysoporthe, and different rates of mutation in the gene regions analyzed. Furthermore, the ITS region failed to recover a statistically supported monophyletic $C$. cubensis. This may be due to incomplete lineage sorting (Hare and Avise 1998; Dettman et al. 2003) that is expected to be present when closely related species are considered (Hudson and Coyne 2002; Rosenberg 2003).

Population genetic analysis of alleles for 12 loci in C. cubensis, C. deuterocubensis and Chrysoporthe austroafricana isolates showed that the levels of differentiation between the populations were not significantly different $(\mathrm{P}<0.05)$. Although the inferred number of migrants between species is relatively high, they are typical for fungi and may be an artefact of close relatedness or incomplete lineage sorting (Stukenbrock et al. 2006; Liu et al. 2009). The allele diversity of the $C$. deuterocubensis population was also higher than that for $C$. austroafricana and C. cubensis (Table 4). These data, therefore, confirmed the observation based on multigene phylogenetic inference that $C$. deuterocubensis represents a distinct species. Additionally, the level of population differentiation reported in this study can be used in future studies considering species delineations in Chrysoporthe, assuming that it is possible to obtain populations of adequate size. Separate species in Chrysoporthe display differentiation values $(\theta)$ of c. $0.27-0.3$, while the 
corresponding number of migrants is c. 1.1-1.3. When new species are considered and the population differentiation increases above 0.3 , the likelihood of complete lineage sorting increases and subsequently, new species can be described based on population genetic data, particularly where phylogenetic data are inconclusive or confusing.

Population assignment tests showed that $C$. deuterocubensis isolates represent a well defined assemblage. However, $C$. deuterocubensis isolates harboured higher frequencies of some alleles that were assigned to $C$. cubensis or C. austroafricana (Fig 2). It is, therefore, possible that $C$. deuterocubensis represents an ancestral species, and that the other species are derived from it. This notion is supported by the fact that $C$. deuterocubensis appears basal to $C$. cubensis and $C$. austroafricana when the joint phylogeny of five gene regions is considered (Fig 1E), and also by the higher allele diversity observed in this species (Table 4).

Africa is the only continent besides South America that harbours different species of Chrysoporthe. Chrysoporthe austroafricana has a wide geographic range and is thought to be native because it occurs on native Syzygium sp. and has not been found outside of Africa (Heath et al. 2006; Nakabonge et al. 2006). Chrysoporthe cubensis has been found in western African countries such as Cameroon, Congo and the Democratic Republic of Congo, while C. deuterocubensis is found in the eastern African countries of Zanzibar (Tanzania), Kenya, Malawi and Mozambique (Nakabonge et al. 2006). Chrysoporthe cubensis and C. deuterocubensis have not been found on any native African hosts in recent surveys (Roux et al. 2003; 2005; Nakabonge et al. 2006) and C. deuterocubensis was also shown to have a low genetic diversity (Nakabonge et al. 2007). These facts suggest that $C$. deuterocubensis was introduced into Africa. The same could be true for C. cubensis in Africa, although population level studies would be necessary to show this conclusively. If this should be true, C. cubensis and C. deuterocubensis do not occur naturally in Africa.

Although C. austroafricana, C. cubensis and C. deuterocubensis occur on a wide range of hosts in the Myrtales, their native hosts in their areas of origin are different. While C. austroafricana was originally found on Eucalyptus trees in South Africa (Wingfield et al. 1989) and where it caused widespread damage, two native hosts, Syzygium cordatum and Syzygium guineense (Myrtaceae), were later discovered (Heath et al. 2006). In contrast, C. cubensis infects native Miconia rubiginosa and Miconia theaezans (Melastomataceae) in South America (Rodas et al. 2005), while $C$.

deuterocubensis was discovered on S. aromaticum (Myrtaceae) and Melastoma melabathricum (Melastomataceae) in Southeast Asia (Myburg et al. 2003; Gryzenhout et al. 2009). Therefore, even though the host ranges of the three fungal species overlap, the native hosts are distinct in the areas where the fungi are thought to be native.

Description of $C$. deuterocubensis now extends the number of known species in the genus to eight, including Chrysoporthe zambiensis, Chrysoporthe syzygiicola (Chungu et al. 2009), C. austroafricana, C. cubensis, Chrysoporthe doradensis, C. inopina and Chrysoporthella hodgesiana (Gryzenhout et al. 2009). Four of these have an apparent Central and South American distribution. Together with $C$. cubensis these include $C$. doradensis, $C$. inopina and $C$. hodgesiana, which are currently known only from Colombia and adjacent Ecuador (Gryzenhout et al. 2004; 2005; 2006b). All of these species, except $C$. doradensis, have been found on native trees (Gryzenhout et al. 2004; $2005 ; 2006$ b). This suggests that these species occur naturally in South America, with this continent currently harbouring the most species of Chrysoporthe.

The segregation of $C$. cubensis and C. deuterocubensis has important quarantine implications. Where these fungi were previously linked to Chrysoporthe canker on Eucalyptus with a single species as the causal agent (Gryzenhout et al. 2004; 2009), the name now encompasses three species including $C$. austroafricana, $C$. cubensis and $C$. deuterocubensis, with geographical ranges that do not overlap. The pathogenicity of $C$. cubensis has been well established in inoculation trials 
on Eucalyptus (Boerboom and Maas 1970; Hodges et al. 1976; Wingfield 2003). Chrysoporthe deuterocubensis is associated with symptoms in Southeast Asia, which are very similar to those caused by C. cubensis in South America. For example, pathogenicity tests on Eucalyptus have been conducted with C. deuterocubensis in Indonesia with results very similar to those for $C$. cubensis (Wingfield 2003). Pegg et al. (2010) have also conducted inoculation trials on Eucalyptus with $C$. deuterocubensis although the fungus in that study was treated as C. cubensis. Both species also have the ability to infect native woody plants in the Melastomataceae and Myrtaceae and could thus cause serious damage if they were accidentally introduced into new environments with native Myrtaceae or Melastomataceae (Gryzenhout et al. 2009).

\section{Acknowledgments}

We are grateful for financial support from Members of the Tree Protection Co-operative Programme (TPCP), the National Research Foundation and the Department of Science and Technology (DST)/National Research Foundation (NRF) Centre of Excellence in Tree Health Biotechnology (CTHB). We also thank Ms Kerry-Anne Pillay and Ms Bafokeng Mpeta for technical assistance.

\section{Literature Cited}

Agapow PM, Burt A, 2001. Indices of multilocus linkage disequilibrium. Molecular Ecology Notes 1: 101-102.

Avise JC, Wollenberg K, 1997. Phylogenetics and the origin of species. Proceedings of the National Academy of Sciences of the United States of America 94: 7748-7755.

Barraclough TG, Nee S, 2001. Phylogenetics and speciation. Trends in Ecology and Evolution 16: 391-399.

Boerboom JHA, Maas PW, 1970. Canker of Eucalyptus grandis and E. saligna in Surinam caused by Endothia havanensis. Turrialba 20: 94-99.

Bruner SC, 1917. Una enfermedad gangrenosa de los eucaliptos. Estacion Experimental Agronomica Bulletin 37: 1-33.

Burt A, Carter DA, Koenig GL, White TJ, Taylor JW, 1996. Molecular markers reveal cryptic sex in the human pathogen Coccidioides immitis. Proceedings of the National Academy of Sciences of the United States of America 93: 770-773.

Carbone I, Kohn LM, 1999. A method for designing primer sets for speciation studies in filamentous ascomycetes. Mycologia 91: 553-556.

Chungu D, Gryzenhout M, Muimba-Kankolongo A, Wingfield MJ, Roux J, 2009. Taxonomy and pathogenicity of two novel Chrysoporthe species from Eucalyptus grandis and Syzygium guineense in Zambia. Mycological Progress 9: 379-393.

Cummings MP, Otto SP, Wakeley J, 1995. Sampling properties of DNA sequence data in phylogenetic analysis. Molecular Biology and Evolution 12: 814-822.

Cunningham CW, 1997. Can three incongruence tests predict when data should be combined? Molecular Biology and Evolution 14: 733-740. 
De Queiros K, 2007. Species concepts and species delimitation. Systematic Biology 56: 879-886.

Dettman JR, Jacobson DJ, Taylor JW, 2003. A multilocus genealogical approach to phylogenetic species recognition in the model eukaryote Neurospora. Evolution 57: 2703-2720.

Edgar RC, 2004. MUSCLE: multiple sequence alignment with high accuracy and high throughput. Nucleic Acids Research 32: 1792-1797.

Farris JS, Källersjo M, Kluge AG, Bult C, 1995. Testing significance of incongruence. Cladistics 10: 315-319.

Fisher MC, Koenig GL, White TJ, Taylor JW, 2002. Molecular and phenotypic description of Coccidioides posadasii sp. nov., previously recognized as the non-California population of Coccidioides immitis. Mycologia 94: 73-84.

Galtier N, Gouy M, Gautier C, 1996. SeaView and PhyloWin: two graphic tools for sequence alignment and molecular phylogeny. Computational and Applied Bioscience 12: 543-548.

GeiserDM, Dorner JW, HornBW, Taylor JW, 2000. The phylogenetics of mycotoxin and sclerotium production in Aspergillus flavus and Aspergillus oryzae. Fungal Genetics and Biology 31: 169-179.

Geiser DM, Pitt JI, Taylor JW, 1998. Cryptic speciation and recombination in the aflatoxinproducing fungus Aspergillus flavus. Proceedings of the National Academy of Sciences of the United States of America 95: 388-393.

Geml J, Laursen GA, O’Neill K, Nusbaum HC, Taylor DL, 2006. Beringian origins and cryptic speciation events in the fly agaric Amanita muscaria. Molecular Ecology 15: 225-239.

Glass NL, Donaldson GC, 1995. Development of primer sets designed for use with the PCR to amplify conserved genes from filamentous ascomycetes. Applied and Environmental Microbiology 61: 1323-1330.

Gryzenhout M, Myburg H, van der Merwe NA, Wingfield BD, Wingfield MJ, 2004. Chrysoporthe, a new genus to accommodate Cryphonectria cubensis. Studies in Mycology 50: 119-142.

Gryzenhout M, Myburg H, Wingfield BD, Montenegro F, Wingfield MJ, 2005. Chrysoporthe doradensis sp. nov. pathogenic to Eucalyptus in Ecuador. Fungal Diversity 20: 39-57.

Gryzenhout M, Myburg H, Wingfield BD, Wingfield MJ, 2006a. Cryphonectriaceae (Diaporthales), a new family including Cryphonectria, Chrysoporthe, Endothia and allied genera. Mycologia 98: 239-249.

Gryzenhout M, Rodas CA, Portales JM, Clegg P, Wingfield BD, Wingfield MJ, 2006b. Novel hosts of the Eucalyptus canker pathogen Chrysoporthe cubensis and a new Chrysoporthe species from Colombia. Mycological Research 110: 833-845.

Gryzenhout M, Wingfield BD, Wingfield MJ, 2006c. New taxonomic concepts for the important forest pathogen Cryphonectria parasitica and related fungi. FEMS Microbiology Letters 258: 161172.

Gryzenhout M, Wingfield BD, Wingfield MJ, 2009. Taxonomy, Phylogeny, and Ecology of Barkinfecting and Tree Killing Fungi in the Cryphonectriaceae. APS Press. 
Guindon S, Gascuel O, 2003. A simple, fast, and accurate algorithm to estimate phylogenies by maximum likelihood. Systematic Biology 52: 696-704.

Hare MP, Avise JC, 1998. Population structure in the American oyster as inferred by nuclear gene genealogies. Molecular Biology and Evolution 15: 119-128.

Heath RN, Gryzenhout M, Roux J, Wingfield MJ, 2006. Discovery of the Cryphonectria canker pathogen on native Syzygium species in South Africa. Plant Disease 90: 433-438.

Hillis DM, Huelsenbeck JP, 1992. Signal, noise, and reliability in molecular phylogenetic analyses. Journal of Heredity 83: 189-195.

Hodges CS, 1980. The taxonomy of Diaporthe cubensis. Mycologia 72: 542-548.

Hodges CS, Alfenas AC, Ferreira FA, 1986. The conspecificity of Cryphonectria cubensis and Endothia eugeniae. Mycologia 78: 343-350.

Hodges CS, Geary TF, Cordell CE, 1979. The occurrence of Diaporthe cubensis on Eucalyptus in Florida, Hawaii, and Puerto Rico. Plant Disease Reporter 63: 216-220.

Hodges CS, Reis MS, Ferreira FA, Henfling JDM, 1976. O cancro do eucalipto causado por Diaporthe cubensis. Fitopatologia Brasileira 1: 129-167.

Hudson RR, Coyne JA, 2002. Mathematical consequences of the genealogical species concept. Evolution 56: 1557-1567.

Ju Y-M, Hsieh H-M, Ho M-C, Szu D-H, Fang M-J, 2007. Theissenia rogersii sp. nov. and phylogenetic position of Theissenia. Mycologia 99: 612-621.

Koufopanou V, Burt A, Szaro T, Taylor JW, 2001. Gene genealogies, cryptic species, and molecular evolution in the human pathogen Coccidioides immitis and relatives (Ascomycota, Onygenales). Molecular Biology and Evolution 18: 1246-1258.

Liu M, Milgroom MG, Chaverri P, Hodge KT, 2009. Speciation of a tropical fungal species pair following transoceanic dispersal. Molecular Phylogenetics and Evolution 51: 413-426.

Milgroom MG, Sotirovski K, Spica D, Davis JE, Brewer MT, Milev M, Cortesi P, 2008. Clonal population structure of the chestnut blight fungus in expanding ranges in southeastern Europe. Molecular Ecology 17: 4446-4458.

Myburg H, Gryzenhout M, Heath R, Roux J, Wingfield BD, Wingfield MJ, 1999a. Cryphonectria canker on Tibouchina in South Africa. Mycological Research 106: 1299-1306.

Myburg H, Gryzenhout M, Wingfield BD, Stipes RJ, Wingfield MJ, 2004. Phylogenetic relationships of Cryphonectria and Endothia species, based on DNA sequence data and morphology. Mycologia 96: 990-1001.

Myburg H, Gryzenhout M, Wingfield BD, Wingfield MJ, 2002. $\beta$-tubulin and histone H3 gene sequences distinguish between Cryphonectria cubensis from South Africa, Asia, and South America. Canadian Journal of Botany 80: 590-596. 
Myburg H, Gryzenhout M, Wingfield BD, Wingfield MJ, 2003. Conspecificity of Endothia eugeniae and Cryphonectria cubensis: a re-evaluation based on morphology and DNA sequence data. Mycoscience 44: 187-196.

Myburg H, Wingfield BD, Wingfield MJ, 1999b. Phylogeny of Cryphonectria cubensis and allied species inferred from DNA analysis. Mycologia 91: 243-250.

Nakabonge G, Gryzenhout M, Wingfield BD, Wingfield MJ, Roux J, 2007. Genetic diversity of Chrysoporthe cubensis in eastern and southern Africa. South African Journal of Science 103: 261264.

Nakabonge G, Roux J, Gryzenhout M,Wingfield MJ, 2006. Distribution of Chrysoporthe canker pathogens on Eucalyptus and Syzygium spp. in eastern and southern Africa. Plant Disease 90: 734740.

Nei M, 1973. Analysis of gene diversity in subdivided populations. Proceedings of the National Academy of Sciences of the United States of America 70: 3321-3323.

O’Donnell K, Ward TJ, Geiser DM, Kistler HC, Aoki T, 2004. Genealogical concordance between the mating type locus and seven other nuclear genes supports formal recognition of nine phylogenetically distinct species within the Fusarium graminearum clade. Fungal Genetics and Biology 41: 600-623.

Old KM, Wingfield MJ, Yuan ZQ, 2003. A Manual of Diseases of Eucalypts in South-East Asia. Centre for International Forestry Research, Jakarta, Indonesia.

Pavlic D, Slippers B, Coutinho TA, Wingfield MJ, 2008. Multiple gene genealogies and phenotypic data reveal cryptic species of the Botryosphaeriaceae: a case study on the Neofusicoccum parvum/N. ribis complex. Molecular Phylogenetics and Evolution 51: 259-268.

Pavlic D, Slippers B, Coutinho TA, Wingfield MJ, 2009. Molecular and phenotypic characterization of three phylogenetic species discovered within the Neofusicoccum parvum/N. ribis complex. Mycologia 101: 636-647.

Pegg GS, Gryzenhout M, O'Dwyer C, Drenth A, Wingfield MJ, 2010. The Eucalyptus canker pathogen Chrysoporthe cubensis discovered in eastern Australia. Australasian Plant Pathology 39: 343-349.

Posada D, 2008. jModelTest: phylogenetic model averaging. Molecular Biology and Evolution 25: 1253-1256.

Pringle A, Baker DM, Platt JL, Wares JP, Latgé JP, Taylor JW, 2005. Cryptic speciation in the cosmopolitan and clonal human pathogenic fungus Aspergillus fumigatus. Evolution 59: 1886-1899.

Pritchard JK, Stephens M, Donnelly P, 2000. Inference of population structure using multilocus genotype data. Genetics 155: 945-959.

Rodas CA, Gryzenhout M, Myburg H, Wingfield BD, Wingfield MJ, 2005. Discovery of the Eucalyptus canker pathogen Chrysoporthe cubensis on native Miconia (Melastomataceae) in Colombia. Plant Pathology 54: 460-470. 
Rosenberg NA, 2003. The shapes of neutral gene genealogies in two species: probabilities of monophyly, paraphyly, and polyphyly in a coalescent model. Evolution 57: 1465-1477.

Roux J, Meke G, Kanyi B, Mwangi L, Mbaga A, Hunter GC, Nakabonge G, Heath RN, Wingfield MJ, 2005. Diseases of plantation forestry trees in eastern and southern Africa. South African Journal of Science 101: 1-5.

Roux J, Myburg H, Wingfield BD, Wingfield MJ, 2003. Biological and phylogenetic analyses suggest that two Cryphonectria spp. cause cankers of Eucalyptus in Africa. Plant Disease 87: 13291332 .

Sharma JK, Mohanan C, Florence EJM, 1985. Occurrence of Cryphonectria canker disease of Eucalyptus in Kerala, India. Annals of Applied Biology 106: 265-276.

Sites JW, Marshall JC, 2003. Delimiting species: a renaissance issue in systematic biology. Trends in Ecology and Evolution 18: 462-470.

Slatkin M, 1995. A measure of population subdivision based on microsatellite allele frequencies. Genetics 139: 457-462.

Slippers B, Stenlid J, Wingfield MJ, 2005. Emerging pathogens: fungal host jumps following anthropogenic introduction. Trends in Ecology and Evolution 20: 420-421.

Sokal RR, Rohlf FJ, 1994. Biometry: the Principles and Practice of Statistics in Biological Research, 3rd edn. Freeman \& Co., San Francisco.

Steenkamp ET, Wingfield BD, Coutinho TA, Wingfield MJ, Marasas WFO, 1999. Differentiation of Fusarium subglutinans f. sp. pini by histone gene sequence data. Applied and Environmental Microbiology 65: 3401-3406.

Steenkamp ET, Wingfield BD, Desjardins AE, Marasas WFO, Wingfield MJ, 2002. Cryptic speciation in Fusarium subglutinans. Mycologia 94: 1032-1043.

Steenkamp ET, Wright J, Baldauf SL, 2006. The protistan origins of animals and fungi. Molecular Biology and Evolution 23: 93-106.

Stukenbrock EH, Banke S, McDonald BA, 2006. Global migration patterns in the fungal wheat pathogen Phaeosphaeria nodorum. Molecular Ecology 15: 2895-2904.

Swofford DL, 2002. PAUP*. Phylogenetic Analysis Using Parsimony (* and other Methods). Version 4.0 beta.

Tamura K, Dudley J, Nei M, Kumar S, 2007. MEGA4: Molecular Evolutionary Genetics Analysis (MEGA) software version 4.0. Molecular Biology and Evolution 24: 1596-1599.

Taylor JW, Jacobson DJ, Fisher MC, 1999. The evolution of asexual fungi: reproduction, speciation and classification. Annual Review of Phytopathology 37: 197-246.

Taylor JW, Jacobson DJ, Kroken S, Kasuga T, Geiser DM, Hibbett DS, Fisher MC, 2000. Phylogenetic species recognition and species concepts in fungi. Fungal Genetics and Biology 31: 21-32. 
van der Merwe NA, Wingfield BD, Wingfield MJ, 2003. Primers for the amplification of sequencecharacterized loci in Cryphonectria cubensis populations. Molecular Ecology Notes 3: 494-497.

Weir BS, Cockerham CC, 1984. Estimating F-statistics for the analysis of population structure. Evolution 38: 1358-1370.

White TJ, Bruns T, Lee S, Taylor J, 1990. Amplification and direct sequencing of fungal ribosomal RNA genes for phylogenies. In: Innes MA, Gelfand DH, Sninsky SS, White TJ (eds), PCR

Protocols: a Guide to Methods and Applications. Academic Press Inc., San Diego, California, pp. 315-322.

Wingfield MJ, 2003. Daniel McAlpine Memorial Lecture. Increasing threat of diseases to exotic plantation forests in the Southern Hemisphere: lessons from Cryphonectria canker. Australasian Plant Pathology 32: 133-139.

Wingfield MJ, Swart WJ, Abear B, 1989. First record of Cryphonectria canker of Eucalyptus in South Africa. Phytophylactica 21: 311-313.

Zhou X, Burgess TI, De Beer ZW, Lieutier F, Yart A, Klepzig K, Carnegie A, Mena Portales J, Wingfield BD, Wingfield MJ, 2007. High intercontinental migration rates and population admixture inthe sapstainfungus Ophiostoma ips. Molecular Ecology 16: 89-99. 